Vol. 9(5), pp. 318-325, 4 February, 2015

DOI: $10.5897 / A J M R 2014.7300$

Article Number: F466BEF50469

ISSN 1996-0808

Copyright (C) 2015

African Journal of Microbiology Research

Author(s) retain the copyright of this article

http://www.academicjournals.org/AJMR

\title{
Distribution of genes encoding aminoglycoside modifying enzymes amongst methicillin resistant and methicillin sensitive Staphylococcus aureus isolates from Nigerian hospitals
}

\author{
Oyebode A. Terry Alli*, David Olusoga Ogbolu, Kunle Paul Bamigboye, \\ Aderayo Aminat Animasaun and Adeolu Oluremi \\ Department of Biomedical Sciences, College of Health Sciences, Ladoke Akintola University of Technology, Osogbo \\ Campus, Osun State, Nigeria.
}

Received 25 November, 2014; Accepted 19 January, 2015

Staphylococcus aureus has long been recognized as one of the major pathogenic organism of human which is responsible for a variety of infections including life threatening infections such as pneumonia. Aminoglycosides antibiotics play an important role in the therapy of staphylococcal infections despite the increase resistant to these drugs. This study aimed at determining the prevalence of genes encoding aminoglycoside modifying enzymes (AMEs) in clinical isolates of $S$. aureus from teaching hospitals in Nigeria. In this study, 86 culture collections of $S$. aureus obtained from 4 teaching hospitals in Nigeria were screened for the presence of genes encoding aminoglycoside resistant genes: $\left(\operatorname{aac}\left(6^{\prime}\right) / a p h\left(2^{\prime \prime}\right)\right.$, aph(3')-IIla, ant(4')-la) and mecA gene by polymerase chain reaction (PCR). Prior to this, antibiotic susceptibility testing was carried out on all the $S$. aureus strains against several antibiotics including gentamicin and cefoxitin. The prevalence of $m e c A$ gene was $44.2 \%$ (38 out of $86 \mathrm{~S}$. aureus). Forty eight $(55.8 \%)$ of the $86 \mathrm{~S}$. aureus identified as gentamicin resistant phenotypically contained at

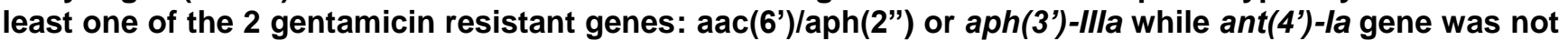
detected in any of the isolates. The $\mathrm{MIC}_{50}$ and $\mathrm{MIC}_{90}$ for gentamicin resistant strains were 32 and $>256$ $\mu \mathrm{g} / \mathrm{ml}$, respectively while the $\mathrm{MIC}_{50}$ and $\mathrm{MIC}_{90}$ for gentamicin sensitive strains were 1 and $8 \mu \mathrm{g} / \mathrm{ml}$, respectively. The prevalence of gentamicin resistant genes was $29.3 \%$ for aac and $19.0 \%$ for aph. No ant gene was detected among the gentamicin resistant strains. SCCmec typing for all the gentamicin resistant methicillin resistant $S$. aureus strains showed diversity of the isolates with $4(17.4 \%)$ out of the 23 were SCCmec II; 4 (17.4\%) out of 23 were SCCmec III and 9 (39.1) out of 23 were SCCmec V while the remaining $8(34.8 \%)$ were non-typeable. Using this scheme gentamicin-methicillin resistant $S$. aureus strains were found to be widely distributed in all the four teaching hospitals studied. The study found an association between genes encoding AMEs and mecA on the genome of $S$. aureus isolates from Nigerian hospitals especially the gentamicin-methicillin resistant $S$. aureus, hence the need for establishment of effective infection control measures and antibiotic policies that will reduce the emergence of gentamicin methicillin resistant strain.

Key words: $\operatorname{aac}\left(6^{\prime}\right) / a p h\left(2^{\prime \prime}\right), a p h\left(3^{\prime}\right)-$ Illa, ant(4')-la genes, gentamicin methicillin resistant Staphylococcus aureus, Nigeria. 


\section{INTRODUCTION}

Aminoglycoside antibiotics have been the cornerstone of effective therapy for bacterial infections including life threatening infections such as pneumonia caused by Staphylococcus aureus. These antibiotics are often combined with a beta lactam antibiotic with synergistic effect (Chadwick et al., 1986; Eliopoulos and Moellering, 1996). Bacterial resistance against aminoglycosides has constituted a major threat to successful antimicrobial treatment of patients. The emergence of methicillin resistant S. aureus (MRSA) in the early 1960s in United Kingdom (Barber, 1961) has made the use of penicillinase resistant penicillin such as methicillin, flucloxacillin, oxacillin, cloxacillin and even cephalosporins in the treatment caused by this strain very difficult. This strain of $S$. aureus has been reported virtually in all the countries of the world with varying frequencies (Dufour et al., 2002; Kesah et al., 2003; Crum et al., 2006). Nigeria has not been exempted from the global epidemic strain (Ghebremedhin et al., 2009; Okon et al., 2009; Alli et al., 2012). The gene encoding the MRSA phenotype has been linked to mecA gene on the chromosome that encodes a modified penicillin binding protein 2 (PBP2). This $m e c A$ gene has been found to be located within a SCCmec cassette within the chromosome and this particular cassette has been found useful in typing the MRSA strains (Zhang et al., 2005). The degree of success that has been achieved in the treatment of staphylococcal infections can be short-lived because of the emergence of aminoglycosides resistant $S$. aureus complicating treatment especially if the strain is MRSA. Aminoglycoside resistance is occasionally caused by intrinsic failure of bacteria to take up drug. However, in most cases, resistance is due to the production by bacteria of an aminoglycoside modifying enzyme (AME), the genetic information for which is acquired by plasmid transfer or another means of gene exchange. About 20 different AMEs are known; and they can be categorized generally into three main groups: acetyltransferases (AACs), phosphotransferases (APHs) and adenylyl transferases (ANTs) (Shaw et al., 1993). Systematic analysis of resistance mechanisms in clinical isolates is indispensable for the design of effective antibiotic policies and could also provide insight into an impending epidemic of antibiotic resistance in $S$. aureus. There is dearth of information on the prevalence of genes encoding AMEs in $S$. aureus from Nigeria apart from the phenotypic description of aminoglycoside resistant $S$. aureus usually described as gentamicin resistant $S$. aureus - being the most commonly available aminoglycoside used for the treatment of staphylococcal infections. It was in view of this that we embarked on the study to examine the clinical isolates of $S$. aureus in Nigeria for the presence of genes encoding AMEs.
Therefore, the aim of the study was to determine the distribution of genes encoding AMEs and mecA gene in clinical isolates of $S$. aureus from Nigerian hospitals including the diversity of SCCmec types within the MRSA with gentamicin resistant phenotype.

\section{MATERIALS AND METHODS}

\section{Bacterial isolates}

A culture collection of eighty six (86) $S$. aureus isolates obtained from non-duplicate 500 clinical specimens from sterile and nonsterile sites including aspirates, ear swab, wound swab, blood, and endocervical swab submitted to four diagnostic laboratories of tertiary health care institutions in Nigeria between July and August 2013 were investigated. The four teaching hospitals were Ladoke Akintola University Teaching Hospital (LTH), Osogbo, Obafemi Awolowo University Teaching Hospital Complex (OAUTHC), Ile-Ife, University College Hospital (UCH), Ibadan and University of llorin Teaching Hospital (UITH), Ilorin, Nigeria. S. aureus identification was based on API 20 Staph kit (Biomerieux, France) and tube coagulase test. All the isolates were stored at $4^{\circ} \mathrm{C}$ on Mueller Hinton $(\mathrm{MH})$ agar slope until ready for use.

\section{Antibiotic susceptibility testing}

The antimicrobial disc susceptibility testing was performed on Mueller Hinton agar. The following antibiotics: penicillin G (10 Units), cefoxitin $(30 \mu \mathrm{g})$, clindamycin $(2 \mu \mathrm{g})$, erythromycin $(15 \mu \mathrm{g})$, tetracycline $(30 \mu \mathrm{g})$, gentamicin $(10 \mu \mathrm{g})$, fusidic acid $(10 \mu \mathrm{g})$ and trimethoprim-sulphamethaxazole $(1.25 / 23.75 \mu \mathrm{g})$ were used to determine the susceptibility pattern of the isolates according to the guidelines of CLSI (2012). S. aureus ATCC 25923 was used as a control strain for the assay.

Susceptibility of $\mathrm{S}$. aureus to vancomycin was determined by using macro dilution technique for minimum inhibitory concentration as described previously with cation adjusted Mueller Hinton broth (CAMHB) (CLSI, 2012). Briefly, about 12 dilutions were made using concentration covering 0.128 to $256 \mu \mathrm{g} / \mathrm{ml}$ of vancomycin. Suspension of the isolates was made to obtain 0.5 MacFarland standard of the organism and $0.05 \mathrm{ml}$ of the suspension was added to each dilution. Three controls were set up; positive control (containing CAMHB and ATCC 25913 strain of $S$. aureus), negative control (containing CAMHB and the antibiotic), and sterility control (containing only CAMHB). MIC breakpoint of $\leq 4 \mu \mathrm{g} / \mathrm{ml}$ was used in defining vancomycin susceptible.

\section{DNA extraction and PCR for detection of mecA gene}

S. aureus suspension was lysed to release DNA from a centrifuged deposit of $5 \mathrm{ml}$ overnight Mueller Hinton broth culture of the organism in $0.5 \mathrm{ml}$ of TES (Tris $\mathrm{HCl} \mathrm{pH} \mathrm{8.0,1} \mathrm{mM} \mathrm{EDTA} \mathrm{and} 0.1 \mathrm{M}$ $\mathrm{NaCl}$ ) containing lysostaphin $(1 \mathrm{mg} / \mathrm{ml}$ ) (Sigma, UK) incubated at $37^{\circ} \mathrm{C}$ for $15 \mathrm{~min}$. After which the DNA was extracted with phenolchloroform, purified and precipitated with ethanol as previously described (Alli et al., 2007). PCR for the mecA gene was carried out on all the strains as previously described (Murakami and Minamide, 1993). Briefly, the DNA template from each isolate was amplified 
Table 1. Antimicrobial susceptibility pattern of $S$. aureus isolates from teaching hospitals in Nigeria

\begin{tabular}{|c|c|c|c|c|c|c|}
\hline Antibiotics & $\begin{array}{l}\text { Number of S. aureus } \\
\text { sensitive isolates (\%) }\end{array}$ & $\begin{array}{l}\text { Number of S. aureus } \\
\text { resistant isolates (\%) }\end{array}$ & $\begin{array}{c}\text { Number of MSSA } \\
\text { sensitive isolates (\%) }\end{array}$ & $\begin{array}{c}\text { Number of MSSA } \\
\text { resistant isolates (\%) }\end{array}$ & $\begin{array}{c}\text { Number of MRSA } \\
\text { sensitive isolates (\%) }\end{array}$ & $\begin{array}{l}\text { Number of MRSA } \\
\text { resistant isolates (\%) }\end{array}$ \\
\hline Clindamycin & $8(9.30)$ & $78(90.7)$ & $5(10.4)$ & $43(89.6)$ & $3(7.9)$ & $35(92.1)$ \\
\hline Erythromycin & $42(48.8)$ & $44(51.2)$ & $22(45.8)$ & $26(54.2)$ & $18(47.4)$ & $20(52.6)$ \\
\hline Gentamicin & 37 (43.0) & $49(57.0)$ & $25(52.1)$ & 23 (47.9) & $13(34.2)$ & $25(65.8)$ \\
\hline $\begin{array}{l}\text { Trimethoprim- } \\
\text { sulphamethaxazole }\end{array}$ & $36(41.9)$ & $50(58.1)$ & $22(45.8)$ & $26(54.2)$ & $14(36.8)$ & $24(63.2)$ \\
\hline Tetracycline & $23(26.7)$ & 63 (73.3) & $18(37.5)$ & $30(62.5)$ & 5 (13.2) & $33(86.8)$ \\
\hline Vancomycin & $86(100)$ & $0(0.0)$ & $48(100)$ & $0(0.0)$ & $38(100)$ & $0(0.0)$ \\
\hline Cefoxitin & $48(55.8)$ & 38 (44.2) & $48(100)$ & $0(0.0)$ & $0(0.0)$ & $38(100)$ \\
\hline Fusidic acid & $17(19.8 \%)$ & $69(80.2)$ & $8(16.7)$ & $40(83.3)$ & $9(23.7)$ & $29(76.3)$ \\
\hline
\end{tabular}

$\%$, percentage; MRSA, methicillin resistant $S$. aureus; MSSA, methicillin sensitive $S$. aureus Gm resistant, Chi square = 5.90; $p$ value = 0.015 between MRSA and MSSA.

using forward primer designated mecA_F1 (AGTTCTGCAGTACCGGATTG) and backward primer designated mecA B1 (AAAATCGATGGTAAGGTTCGC) in a $30 \mu \mathrm{l}$ reaction containing $50 \mathrm{ng}$ of DNA, Taq polymerase and dNTP using the cycling parameter - denaturation temperature at $94^{\circ} \mathrm{C}$ for $30 \mathrm{~s}$, annealing temperature at $55^{\circ} \mathrm{C}$ for $30 \mathrm{~s}$, followed by extension at $72^{\circ} \mathrm{C}$ for $1 \mathrm{~min}$ for 40 cycles. Positive control (MRSA DNA) and negative control DNA from NCTC 6571 (Oxford S. aureus) were included in each batch of PCR run.

\section{PCR Amplication of $\operatorname{aac}\left(6^{\prime}\right) / a p h\left(2^{\prime \prime}\right), a p h\left(3^{\prime}\right)-I l l a$ and ant(4')-la genes}

Simplex PCR amplication of $\operatorname{aac}\left(6^{\prime}\right) / a p h\left(2^{\prime \prime}\right)$, aph(3')-IIla and ant(4')-la genes was carried out as previously described by Choi et al. (2003) using the following forward and backward primers, 5'-GAAGTACGCAGAAGAGA-3' and 5'-ACATGGCAAGCTCTAGAA-3'; 5'AAATACCGCCTGCGTA-3' and 5'CATACTTCTTCCGAGCAA $\quad-3^{\prime} ;$ AATCGGTAGAAGCCCAA-3' and 5' GCACCTGCCATTGCTA, respectively. The PCR mix was in a $30 \mu \mathrm{l}$ reaction volume as described for $m e c A$ amplification with the following cycling parameters: denaturation at $95^{\circ} \mathrm{C}$ for $2 \mathrm{~min}$; annealing at $54^{\circ} \mathrm{C}$ for 1 min; extension at $72^{\circ} \mathrm{C}$ for $1 \mathrm{~min}$; for 30 cycles using
GeneAmp PCR system 9700 thermal cycler (Applied Biosystems, UK). The expected product sizes of 491, 242 and $135 \mathrm{bp}$, respectively were used to determine successful amplification of the genes.

\section{scCmec typing}

SCCmec typing of all the mecA+ isolates of $S$. aureus was carried out as previously described (Zhang et al., 2005) using PCR technology. The PCR products were analysed on agarose gel containing $0.5 \mu \mathrm{g} / \mathrm{ml}$ ethidium bromide following electrophoresis and the image captured using Sygene Gel documentation system (Sygene, UK).

\section{Statistical analysis}

Data were analysed using statistical package within the Microsoft Excel and Epi-info software for Centre for Disease Control and Prevention, USA. The $p$ value $<0.05$ was considered to be significant.

\section{RESULTS}

The result of the antibiotic susceptibility pattern of the culture collections from 4 tertiary hospitals in
Nigeria mainly from South-Western region of the country is shown in Table 1. Varying degrees of susceptibility to antibiotics were observed with highest degree of antibiotic resistance observed for penicillin where all the isolates examined were resistant to penicillin. The highest degree of antibiotic sensitivity was observed in vancomycin where all the clinical isolates $(100 \%)$ of $S$. aureus were susceptible using MIC breakpoint of $\leq 4$ $\mu \mathrm{g} / \mathrm{ml}$ according to CLSI (2012) (Table 1). All the isolates were screened for mecA gene and the result show that $38(44.2 \%)$ of the 86 isolates possessed mecA gene indicating there were 38 methicillin resistant $S$. aureus (MRSA) and 48 methicillin sensitive $S$. aureus (MSSA) isolates. This result conformed with the result of the cefoxitin $(30 \mu \mathrm{g})$ disc susceptibility testing. On the basis of these, the isolates were divided into two: MRSA and MSSA. The MRSA strains appeared to be more resistant to antibiotics than MSSA (Table 1) but there was no significant difference in the susceptibility patterns of the isolates (Chi square = $5.61 ; P=0.469$ ). However, there was a significant difference in the resistance of MRSA and MSSA 
Table 2. Distribution of $\operatorname{aac}\left(6^{\prime}\right) / a p h\left(2^{\prime \prime}\right)$ and $a p h\left(3^{\prime}\right)-I I l a$ genes amongst $S$. aureus isolates.

\begin{tabular}{|c|c|c|c|c|c|c|c|c|c|c|}
\hline & mecA+ & $\%$ mecA+ & mecA- & $\%$ mecA- & Gm res & $\%$ Gm res & Gm sens & $\%$ Gm sens & mecA+ Gm res & $\%$ mecA+ Gm res \\
\hline \multicolumn{11}{|c|}{$\operatorname{aph}\left(3^{\prime}\right)-I I l a$} \\
\hline Negative & 21 & 55.3 & 32 & 66.7 & 12 & 24.5 & 22 & 59.5 & 1 & 50.0 \\
\hline Positive & 17 & 44.7 & 16 & 33.3 & 37 & 75.5 & 15 & 40.5 & 1 & 50.0 \\
\hline \multicolumn{11}{|c|}{$\operatorname{aac}\left(6^{\prime}\right) / a p h\left(2^{\prime \prime}\right)$} \\
\hline Negative & 9 & 23.7 & 30 & 62.5 & 19 & 38.8 & 22 & 59.5 & 1 & 50.0 \\
\hline Positive & 29 & 76.3 & 18 & 37.5 & 30 & 61.2 & 15 & 40.5 & 1 & 50.0 \\
\hline \multicolumn{11}{|c|}{$a p h\left(3^{\prime}\right)-I I l a$ and $a a c\left(6^{\prime}\right) / a p h\left(2^{\prime \prime}\right)$} \\
\hline Negative & 2 & 8.0 & 10 & 62.5 & 4 & 23.5 & 8 & 57.1 & 2 & 8.0 \\
\hline Positive & 23 & 92.0 & 6 & 37.5 & 13 & 76.5 & 6 & 42.9 & 23 & 92.0 \\
\hline
\end{tabular}

Test of association between having aac(6')/aph(2") and aph(3')-Illa genes and methicillin resistant gentamicin resistant $S$. aureus $($ Chi square $=6.197 ; \mathrm{P}=0.0127)$. Gm res gentamicin resistant; Gm sens - gentamicin sensitive.

to gentamicin (Chi square $=5.90 ; P=0.015$ ). Overall, methicillin and gentamicin resistant $S$. aureus represented $29.1 \%$ of the 86 clinical isolates of $S$. aureus. The $\mathrm{MIC}_{50}$ and $\mathrm{MIC}_{90}$ to gentamicin for gentamicin resistance isolates were 32 and $>256 \mu \mathrm{g} / \mathrm{ml}$, respectively indicating high level of resistance to gentamicin while that of gentamicin sensitive isolates $\mathrm{MIC}_{50}$ and $\mathrm{MIC}_{90}$ were 1 and $8 \mu \mathrm{g} / \mathrm{ml}$, respectively. Twenty one $(26.6 \%)$ of the 79 clindamycin resistant $S$. aureus were inducible clindamycin resistance as detected by the double disc diffusion method giving $24.4 \%$ of the total $S$. aureus examined. It was found that $11(52.4 \%)$ of 21 inducible clindamycin resistance were MRSA while the remaining 10 (47.6\%) were MSSA.

PCR detection of $\left(\operatorname{aac}\left(6^{\prime}\right) / a p h\left(2^{\prime \prime}\right)\right.$ and $a p h\left(3^{\prime}\right)-1 / l a$, genes showed that there were varying distributions of $\left(\operatorname{aac}\left(6^{\prime}\right) / a p h\left(2^{\prime \prime}\right)\right.$ and $a p h\left(3^{\prime}\right)$-IIla genes amongst the $S$. aureus isolates (Table 2). Highest prevalence of aac(6')/aph(2") gene representing $47(54.7 \%)$ of 86 was recorded for clinical isolates of $S$. aureus followed by $a p h\left(3^{\prime}\right)$ -
Illa gene where $33(38.4 \%)$ out of 86 clinical isolates of $S$. aureus were detected. No ant $\left(4^{\prime}\right)$-la gene was detected in all the $86 \mathrm{~S}$. aureus isolates.

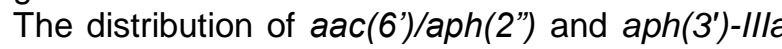
genes in mecA+ and mecA-S. aureus is shown in Table 2. There was no association between aph( $\left.3^{\prime}\right)$-IIla gene and mecA+/mecA- strains of $S$ aureus (Chi square $=0.73 ; \mathrm{P}=0.39$ ). However, association was found between aac (6')/aph(2") gene and $m e c A+/ m e c A$ - strains of $S$. aureus (Chi square $=11.38 ; \mathrm{P}=0.007)$. The distribution of genes encoding AMEs showed that more of aph $\left(3^{\prime}\right)$-IIla gene was detected in gentamicin resistant $S$. aureus isolates $(75.5 \%)$ than gentamicin sensitive isolates $(40.5 \%)$, that is, association was found between the presence of this gene and gentamicin resistant $S$. aureus isolates (Chi square $=9.37 ; \mathrm{P}=0.0022$ ) while 30 $(61.2 \%)$ of 49 gentamicin resistant $S$. aureus were positive for aac(6')/aph(2") gene and $15(40.5 \%)$ out of 37 gentamicin sensitive $S$. aureus were positive for $\operatorname{aac}\left(6^{\prime}\right) / a p h\left(2^{\prime \prime}\right)$ gene. No association was found between $\operatorname{aac}\left(6^{\prime}\right) / a p h\left(2^{\prime \prime}\right)$ gene and gentamicin resistant $S$. aureus isolates in this study (Chi square $=2.83 ; \mathrm{P}=0.09$ ). It is noteworthy that there was strong association between genes encoding AMEs (aph( $\left.3^{\prime}\right)$-IIla and aac(6')/aph(2") genes) and mecA+ gentamicin resistant $S$. aureus isolates (Chi square $=16.85 ; \mathrm{P}$ $=0.000038)$. Twenty three $(26.7 \%)$ of the $86 \mathrm{~S}$. aureus isolates examined in this study constituted the $m e c A+$ gentamicin resistant $S$. aureus isolates. The result of the SCCmec typing for all the gentamicin resistant methicillin resistant $S$. aureus strains showed that $4(17.4 \%)$ out of the 23 were SCCmec II; 4 (17.4\%) out of 23 were $\mathrm{SCC} m e c$ III and 9 (39.1) out of 23 were SCCmec $\mathrm{V}$, while the remaining $8(34.8 \%)$ were nontypeable using this scheme. This could be interpreted as 8 of the 23 gentamicin resistant, methicillin resistant $S$. aureus strains were most likely to be hospital acquired strains, that is, $\mathrm{SCC} m e c$ II and III while the SCCmec V was considered to be community acquired strains. The interpretation was based on the fact that large SCCmec I to III had been found to be associated 


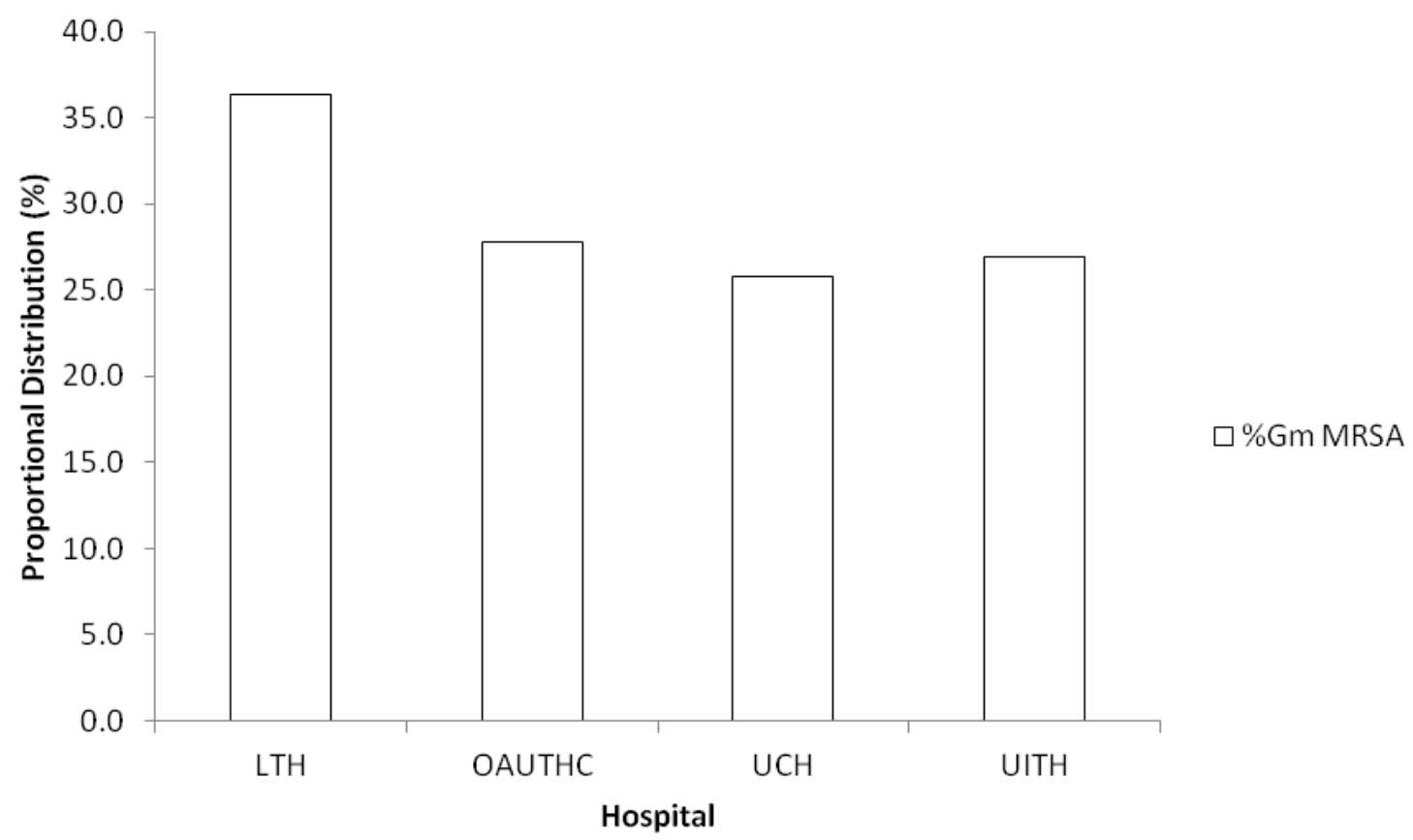

Figure 1. Proportional distribution of gentamicin methicillin resistant $S$. aureus amongst four teaching hospitals in Nigeria.

with HA-MRSA while SCC mec IV and V had been found to be associated with CA-MRSA (Ma et al., 2002; David and Daum, 2010). The proportional distribution of gentamicin methicillin resistant $S$. aureus amongst the 4 teaching hospitals in Nigeria is shown on Figure 1. Highest prevalence of this strain was recorded at LTH while $\mathrm{UCH}$ recorded the lowest. There was no association between hospital and gentamicin methicillin resistant $S$. aureus (Chi square $=0.25 ; P=0.97$ ). The proportional distribution of genes encoding aminoglycosides modifying enzymes and $\operatorname{mec} A$ gene is shown on Figure 2. LTH recorded highest prevalence (8 $(80 \%)$ out of 10$)$ of $\operatorname{aac}\left(6^{\prime}\right) / a p h\left(2^{\prime \prime}\right)$ gene; UITH recorded the lowest prevalence (13 $(50 \%)$ out of 26$)$ of this gene. No association was found between prevalence of aac(6')/aph(2") gene and hospitals (Chi square 3.46; $\mathrm{P}=$ 0.326). Similarly, no associations were found with aph $\left(3^{\prime}\right)$-IIla gene (Chi square $\left.=1.40 ; P=0.71\right)$, mecA gene $($ Chi square $=4.00 ; P=0.26)$ and hospitals.

\section{DISCUSSION}

Methicillin resistant $S$. aureus (MRSA) has been reported all over the world in clinical isolates with varying frequency (Crum et al., 2006; Diep et al., 2008; Egyir et al., 2014) including Nigeria where studies have shown general increase in the prevalence of this strain of $S$. aureus (Alli et al., 2012). In this present study, survey of MRSA amongst clinical isolates of $S$. aureus from 4 tertiary hospitals in Nigeria was undertaken along with antimicrobial susceptibility pattern of the isolates. The prevalence of MRSA was found to be $44.2 \%$ in this study as compared to $41.2 \%$ obtained about 2 years ago in this area (Alli et al., 2012). The antimicrobial susceptibility patterns of the clinical isolates of $S$. aureus also showed general increase in the prevalence of bacteria resistance to other with the exception of vancomycin that has been shown to be active against these isolates. This study is in contrast with a report at a nearby country - Ghana where the prevalence of antibiotics resistant has been found to be low (Egyir et al., 2014). MRSA has been shown over the years to have propensity for antibiotic resistance. This present study found that there was no significant difference in the antibiotics susceptibility patterns between MRSA and MSSA ( $P>0.05)$; this is a worrying trend in this part of the world.

Aminoglycosides group of antibiotics especially gentamicin has been the cornerstone for the treatment of infection caused by $S$. aureus especially when it is used along with $\beta$-lactamase resistant penicillin or cephalosporin for the treatment of infective endocarditis. In this study, the prevalence of gentamicin resistant $S$. aureus was found to be $55.8 \%$; higher than what the study reported for MRSA. This study is comparable to what was obtained in this locality in Nigeria where $56.5 \%$ was obtained (Alli et al., 2012). Interestingly, recent report from Ghana, a closest neighbour to Nigeria showed 3\% (Egyir et al., 2014). S. aureus resistance to gentamicin is essentially as a result of acquisition of genes encoding aminoglycosides modifying enzymes 




Figure 2. Proportional distribution of genes encoding aminoglycoside modifying enzymes and mecA gene in $S$. aureus isolates from four teaching hospitals in Nigeria.

(aac(6')/aph(2'), aph(3')-IIla and ant(4')-la genes). The study did not detect the ant(4')-la gene amongst the gentamicin resistant $S$. aureus nor gentamicin sensitive isolates which is in contrast with a study carried out in South Korea where prevalence of this gene was found to be $41 \%$. The product of ant(4')-la gene (Ant 4 ") has activity against neomycin, kanamycin, tobramycin and amikacin in staphylococci. None detection of this gene amongst clinical isolates of $S$. aureus in Nigeria may have something to do with little or no usage of these antibiotics in the treatment of infections or the sample size used in this study. The prevalence of aac(6')/aph(2") gene was found to be $54.7 \%$ in $S$. aureus isolates examined as compared to $65 \%$ obtained by Choi et al. (2003), this suggests the widespread of this gene. In gentamicin resistant isolates, the prevalence of aac(6')/aph(2") gene was found to be $61.2 \%$ which is in contrast to $100 \%$ obtained in a study by Choi et al. (2003).
Conversely, the prevalence of aph(3')-IIla gene was found to be $75 \%$ amongst the gentamicin resistant $S$. aureus. This prevalence is very high as compared to what was obtained in Iran where Yadegar et al. (2009) reported $6 \%$ prevalence amongst the clinical isolates of $S$. aureus and the prevalence of $9 \%$ reported in South Korea by Choi et al. (2003). In gentamicin sensitive $S$. aureus isolates in our study, we found the prevalence of aph $\left(3^{\prime}\right)$-IIla gene to be $40.5 \%$ suggesting that this gene does not necessarily confer resistance to gentamicin alone. aph $\left(3^{\prime}\right)$-IIla gene has been shown from previous study to mediate resistance to kanamycin, neomycin, gentamicin and amikacin (Shaw et al., 1993), suggesting cross resistance to other aminoglycosides. Gentamicin is used more regularly in treating infections than other aminoglycosides in Nigeria especially when used in conjunction with penicillin to treat endocarditis. Interestingly, our study showed $92 \%$ concordance to gentamicin resistant when we had co-occurrence of two 
aminoglycoside modifying enzyme genes (aac(6')/aph(2") and aph( $\left.\left.3^{\prime}\right)-I I l a\right)$ in $S$. aureus isolates with mecA gene in gentamicin-methicillin resistant $S$. aureus strains. The importance of this finding to diagnosis and treatment cannot be overemphasized because there is most likely to be clinical failure if gentamicin is used in treating infection caused by gentamicin-methicillin resistant $S$. aureus as a result of the resistant of these strains to gentamicin that would be brought about by the full expression of the resistance genes. Several studies have linked aminoglycoside resistance to methicillin resistance (Choi et al., 2003; Schmitz et al., 1999; Shaw et al., 1993), this study also observed a similar trend. The result of the SCCmec showed that the gentamicin methicillin resistant $S$. aureus is diverse because it is not restricted to one SCCmec type and one teaching hospital. Although more is needed to be done in this area in order to determine the clonality of this strain, but this does not rule out the importance of this technique in giving a snapshot of the diversity of this strain in developing countries like ours.

To conclude, this study has shown the importance of genes encoding aminoglycoside modifying enzymes in gentamicin resistant $S$. aureus and also the emergence of gentamicin-methicillin resistant $S$. aureus that can complicate treatment of endocarditis where combination therapy such as gentamicin and beta-lactamase resistant penicillin is employed because of synergistic effect of these antibiotics. Hence, there is need for constant surveillance of gentamicin methicillin resistant $S$. aureus strains in our community with good infection control policy that could curb the spread of this strain. Further work is needed to detect and characterize the plasmid backbones or vectors underpinning these resistance determinants and also determine the effect of fitness cost result from acquisition of antibiotic resistance of these strains. The use of genes encoding AMEs and mecA in screening for gentamicin methicillin resistant strain of $S$. aureus should be encouraged as employed by Choi et al. (2003) in multiplex PCR.

\section{ACKNOWLEDGEMENTS}

The authors would like to acknowledge the assistance received from the Medical Laboratory Scientists of Department of Medical Microbiology and Parasitology of the following hospitals: Obafemi Awolowo University Teaching Hospital Complex, Ile-lfe, Nigeria; Ladoke Akintola University of Technology Teaching Hospital, Osogbo; University of llorin Teaching Hospital, Ilorin and University College Hospital, Ibadan, Nigeria. We would also like to acknowledge Mr M. Oyenike for his technical assistance in the execution of this study.

\section{Conflict of interest}

No conflict of interest is reported in this study.

\section{REFERENCES}

Alli O, Akinloye O, Rowley D Butcher P (2007). A comparative assessment of ribosomal DNA polymorphisms in methicillin resistant Staphylococcus aureus (MRSA) epidemiology. Afr. J. Biomed. Res. 10(2): 117-125

Alli OAT, Ogbolu DO, Mustapha JO, Akinbami R, Ajayi AO (2012). The non-association of Panton-Valentine leukocidin and mecA genes in the genome of Staphylococcus aureus from hospitals in South Western Nigeria. Indian J. Med. Microbiol. 30(2):159-164.

Barber M (1961). Methicillin-resistant staphylococci. J. Clin. Pathol. 14:385-393

Chadwick EK, Shulman ST, Yogev R (1986). Correlation of antibiotic synergy in vitro and in vivo: Use of an animal model of neutropenic Gram negative sepsis. J. Infect. Dis. 154:670-675.

Choi SM, Kim SH, Kim HJ, Lee DG, Choi JH, Yoo JH, Kang JH, Shin WS, Kang MW (2003). Multiplex PCR for the detection of genes encoding aminoglycoside modifying enzymes and methicillin resistance among Staphylococcus species. J. Korean Med. Sci. 18(5):631-636.

CLSI (2012). Performance Standards for Antimicrobial Susceptibility Testing; Twenty-Second Informational Supplement M100-S22 Vol.32 No. 3.

Crum N, Lee R, Thornton S, Stine O, Wallace M, Barrozo C, KeeferNorris A, Judd S, Russell K (2006). Fifteen-year study of the changing epidemiology of methicillin-resistant Staphylococcus aureus. Am. J. Med. 119(11):943-951.

David MZ, Daum RS (2010). Community-associated methicillin-resistant Staphylococcus aureus: Epidemiology and Clinical Consequences of an emerging epidemic. Clin. Microbiol. Rev. 23(3):616-687.

Diep BA, Chambers HF, Graber CJ, Szumowski JD, Miller LG, Han LL, Chen JH, Lin F, Lin J, Phan TH, Carleton HA, McDougal LK, Tenover FC, Cohen DE, Mayer KH, Sensabaugh GF, Perdreau-Remington, F (2008). Emergence of multidrug-resistant, community-associated, methicillin-resistant Staphylococcus aureus clone USA300 in men who have sex with men. Ann. Intern. Med. 148(4):249-257.

Dufour P, Gillet Y, Bes M, Lina G, Vandenesch F, Floret D, Etienne J, Richet H (2002). Community-acquired methicillin-resistant Staphylococcus aureus infections in France: emergence of a single clone that produces Panton-Valentine leukocidin. Clin Infect Dis. 35(7):819-824.

Egyir B, Guardabassi L, Sorum M, Nielsen SS, Kolekang A, Frimpong E, Addo KK, Newman MJ, Larsen AR (2014). Molecular epidemiology and antimicrobial susceptibility of clinical Staphylococcus aureus from healthcare institutions in Ghana. PLoS One 9:e89716.

Eliopoulos GM, Moellering RC (1996). Antimicrobial combinations. In: Lorian V, ed. Antibiotics in Laboratory Medicine. $4^{\text {th }}$ ed. Baltimore: Williams \& Wilkins. pp. 330-383.

Ghebremedhin B, Olugbosi MO, Raji AM, Layer F, Bakare RA, Konig B, Konig W (2009). Emergence of a community-associated methicillinresistant Staphylococcus aureus strain with a unique resistance profile in Southwest Nigeria. J. Clin. Microbiol 47(9):2975-2980.

Kesah C, Ben Redjeb S, Odugbemi TO, Boye CS, Dosso M, Ndinya Achola JO, Koulla-Shiro S, Benbachir M, Rahal K, Borg M. (2003). Prevalence of methicillin-resistant Staphylococcus aureus in eight African hospitals and Malta. Clin. Microbiol. Infect. 9(2):153-156.

Ma XX, Ito T, Tiensasitorn C, Jamklang M, Chongtrakool P, BoyleVavra S, Daum RS, Hiramatsu K (2002). Novel type of staphylococcal cassette chromosome mec identified in communityacquired methicillin-resistant Staphylococcus aureus strains. Antimicrob. Agents Chemother. 46(4):1147-1152.

Murakami K, Minamide W (1993). PCR identification of methicillinresistant Staphylococcus aureus. In Diagnostic Molecular Microbiology: Principles and Applications. pp. 534-538. Edited by Persing D, Smith T, Tenover F, White T. Washington, DC: American Society for Microbiology.

Okon KO, Basset P, Uba A, Lin J, Oyawoye B, Shittu AO, Blanc DS (2009). Cooccurrence of predominant Panton-Valentine leukocidinpositive sequence type (ST) 152 and multidrug-resistant ST 241 Staphylococcus aureus clones in Nigerian hospitals. J. Clin. Microbiol. 47(9):3000-3003.

Schmitz FJ, Fluit AC, Gondolf M, Beyrau R, Lindenlauf E, Verhoef J, 
Heinz HP, Jones ME (1999). The prevalence of aminoglycoside resistance and corresponding resistance genes in clinical isolates of staphylococci from 19 European hospitals. J. Antimicrob. Chemother. 43(2):253-259.

Shaw KJ, Rather PN, Hare RS, Miller GH (1993). Molecular genetics of aminoglycoside resistance genes and familial relationships of the aminoglycoside-modifying enzymes. Microbiol. Rev. 57(1):138-163.

Yadegar A, Sattari M, Mozafari NA, Goudarzi GR (2009). Prevalence of the genes encoding aminoglycoside-modifying enzymes and methicillin resistance among clinical isolates of Staphylococcus aureus in Tehran, Iran. Microb. Drug Resist. 15(2):109-113.
Zhang K, McClure JA, Elsayed S, Louie T, Conly JM (2005). Novel multiplex PCR assay for characterization and concomitant subtyping of staphylococcal cassette chromosome mec types I to $\mathrm{V}$ in methicillin-resistant Staphylococcus aureus. J. Clin. Microbiol. 43(10):5026-5033. 